Article

\title{
Phytotoxic and Genotoxic Effects of Copper Nanoparticles in Coriander (Coriandrum sativum-Apiaceae)
}

\author{
Alya O. AlQuraidi ${ }^{1}$, Kareem A. Mosa ${ }^{1,2, *}$ and Kalidoss Ramamoorthy ${ }^{1}$ \\ 1 Department of Applied Biology, College of Sciences, University of Sharjah, Sharjah P.O. Box 27272, UAE; \\ u16101516@sharjah.ac.ae (A.O.A.); kramamoorthy@sharjah.ac.ae (K.R.) \\ 2 Department of Biotechnology, Faculty of Agriculture, Al-Azhar University, Cairo, Egypt \\ * Correspondence: kmosa@sharjah.ac.ae; Tel.: +971-6-505-3838; Fax: +971-6-505-3814
}

Received: 24 October 2018; Accepted: 5 January 2019; Published: 14 January 2019

\begin{abstract}
Engineered metal nanoparticles have been widely used in several applications that may lead to increased exposure to the environment. In this study, we assessed the phytotoxic effect of various concentrations of copper nanoparticles CuNP, (200, 400 and $800 \mathrm{mg} / \mathrm{L})$ on coriander (Coriandrum sativum) plants grown hydroponically. C. sativum plants treated with CuNP demonstrated decreased biomass and root length in comparison to control untreated plants. Additionally, decreased levels of photosynthetic pigments (chlorophyll $a$ and $b$ ) were also seen in C. sativum plants treated with CuNP, as well as damage to the $C$. sativum root plasma membrane as demonstrated by Evan's blue dye and increased electrolyte leakage. Moreover, our results exhibited increased levels of $\mathrm{H}_{2} \mathrm{O}_{2}$ and MDA on C. Sativum plants treated with CuNP. X-Ray Fluorescence (XRF) analysis confirmed that $C$. sativum treated with CuNP accumulated the latter in plant root tissues. Random amplified polymorphic DNA (RAPD) analysis confirmed the genotoxic effect of CuNP, which altered the C. sativum genome. This was shown by the different banding pattern of RAPD. Overall, our results exhibited that $\mathrm{CuNP}$ is toxic to $C$. sativum plants.
\end{abstract}

Keywords: Coriandrum sativum; phytotoxicity; genotixicity; CuNP; RAPD; XRF

\section{Introduction}

Nanoparticles are nano-scale particles or atomic aggregates with at least one dimension between 1 and $100 \mathrm{~nm}$. Nanoparticles have been a great source of concern in recent years due to their extensive usage in many industries (including agriculture). They have been used in many applications in agriculture including pesticides, fungicides and fertilizers [1]. Depending on their origin, further distinctions can be made. There are naturally occurring, incidental and engineered nanoparticles (ENPs). Major naturally occurring nanoparticles can be found in the atmosphere: volcanic eruptions, desert surfaces, dust from cosmic sources located in the solar system such as iron oxides that can be found in water, soil and sediments of earth crust [2]. Incidental nanoparticles are produced as side products of anthropogenic activities whereas Engineered Nanoparticles (ENPs) are produced intentionally for their extensive usage in various implications including biomedical, electronic and industrial. They express specific sizes and shapes, which can enter the environment through air, water and soil [3].

Due to the wide range of implications, the utilization of ENPs in various fields (including industrial, medical, mechanical and agriculture) can result in increased exposure to our environment [4]. Examples of widely used ENPs include silver nanoparticles (AgNP), which are present in products like cosmetics, clothing and household items [5]. Additionally, iron nanoparticles (FeNP) are found 
in concrete additives [6]. Lead nanoparticles (PbNP) are found in automotive exhaust converters [6], while cobalt nanoparticles (CoNP) are used in biomedical and health science applications [6-8]. Copper nanoparticles (CuNP) are involved in the production of temperature and pressure sensors $[7,8]$ Regardless of their benefits to several industries, questions on how ENPs are affecting the environment and interacting with living organisms have been put forward in recent times. Due to their extensive utilization, nanoparticle traces are inadvertently released at different stages of their production and usage, raising concerns of their potential risks. Although several ENPs have exhibited beneficial effects on crops, phytotoxic assessment would still be recommended depending on the size, shape, zeta potentials, concentrations, transportation, transformation, dosage and the plant species of the involved nanoparticles. Recently, several studies and experiments have been performed to evaluate the effect of ENPs on the environment in terms of direct exposure and long-term accumulation. The size of the ENPs can determine the amount of toxicity, with a larger surface area allowing increased interaction with the environment [9].

Several metals act as micronutrients including copper are essential in small quantities for the proper functioning of biological systems. In plants, copper is particularly important for the synthesis of lignin and several other enzyme systems such as $\mathrm{Cu} / \mathrm{Zn}$ superoxide dismutase (SOD), cytochrome $\mathrm{c}$ oxidase, amino oxidase, laccase, plastocyanin and polyphenol oxidase [10], photosynthesis and the metabolism of carbohydrates and proteins [11]. However, high concentrations of such metals can adversely lead to reduced growth, altered metabolism, less biomass and metal accumulation [12]. Furthermore, if metals are present in the form of nanoparticles, the resulting effects would be largely unpredictable due to size and shape differences [13]. As plants are an important part of the environment, the potential negative effects of metal nanoparticles in their case have been an increasing concern. In the past decade, several studies have described the phytotoxic effects of ENPs on plants [14]. However, divulging detailed mechanisms of phytotoxicity have still been elusive. Therefore, toxicological studies should be undertaken to evaluate the fate of nanoparticles, their toxic effect, transformation and distribution in plants, in addition to their effect on the physiological, biochemical and molecular aspects.

As copper is as an essential constituent in plants, CuNPs have been utilized as antimicrobial agents for biocidal activity $[15,16]$. In addition, CuNPs are used in agriculture as an effective nano-metallic fungicide application in crops to protect against fungal diseases [17,18].

Curcubita pepo (zucchini) treated with CuNP and bulk copper powder showed $77 \%$ and $64 \%$ of root length reduction, respectively, when compared to control plants. Additionally, their exposure also resulted in a 90\% reduction in biomass [19]. CuNPs have also been observed to significantly reduce seedling growth in Elsholtzia splendens grown in a hydroponic system treated with different concentrations of copper particles; 100, 200, 500, $1000 \mathrm{mg} / \mathrm{L} \mathrm{CuONP,} 1000 \mathrm{mg} / \mathrm{L} \mathrm{CuOBPs}$, and $0.5 \mathrm{mg} / \mathrm{L}$ soluble $\mathrm{Cu}$ [20], as well as reducing root and shoot growth, and chlorophyll and carotenoids contents of Indian mustard [21]. Other than morphological changes, CuNPs can also affect the biochemical content of plants as demonstrated by reduced chlorophyll content and increased hydrogen peroxide and lipid peroxidation resulting in increased reactive oxygen species (ROS) production in cucumbers [22]. The effect of the copper nanoparticle also extends to the DNA level by inducing DNA damage in radish and grasses [23], as well as cucumbers [22].

Coriander (Coriandrum sativum) is an annual herb and food leaf crop, which is used in many parts of the world for food and medicinal purposes, and therefore was chosen for this study to evaluate the phytotoxic and genotoxic effect of CuNP. C. sativum was treated with CuNPs of size $\sim 20 \mathrm{~nm}$ with different concentrations $(200,400 \& 800 \mathrm{mg} / \mathrm{L})$ and the plants were grown in a hydroponic system to maintain the dosage of the nanoparticle. Hence, the impact of CuNP was analyzed at morphological, physiological, and molecular levels. 


\section{Results}

\subsection{CuNP Decreased C. sativum Root Length, Biomass, and Chlorophyll Content}

Plants treated with different concentrations of CuNPs exhibited differences in the biomass and root length after seven days of the treatment (Figure 1a,b). Treated roots exhibited a different morphology with weaker, thinner and reduced adventitious roots, whereas the shoots showed no changes. There was no significance difference between control and $200 \mathrm{mg} / \mathrm{L}$ CuNP treated plants. However, 400 and $800 \mathrm{mg} / \mathrm{L}$ of CuNP treated plants showed statistically significant reduction with more than $35 \%$ biomass decrease compared with the control untreated plants (Figure 1b). Additionally, root length analysis between control plants showed enhanced root growth and the production of more adventitious roots, whereas treated (200, 400 and $800 \mathrm{mg} / \mathrm{L})$ plants had reduced root growth. Differences between control and treated plants with different CuNPs concentrations were dose dependent, the reduction being statistically significant with around 17\% root length decrease in $400 \mathrm{mg} / \mathrm{L}$ and $800 \mathrm{mg} / \mathrm{L} \mathrm{CuNPs}$ treated plants (Figure 1c).

(a)
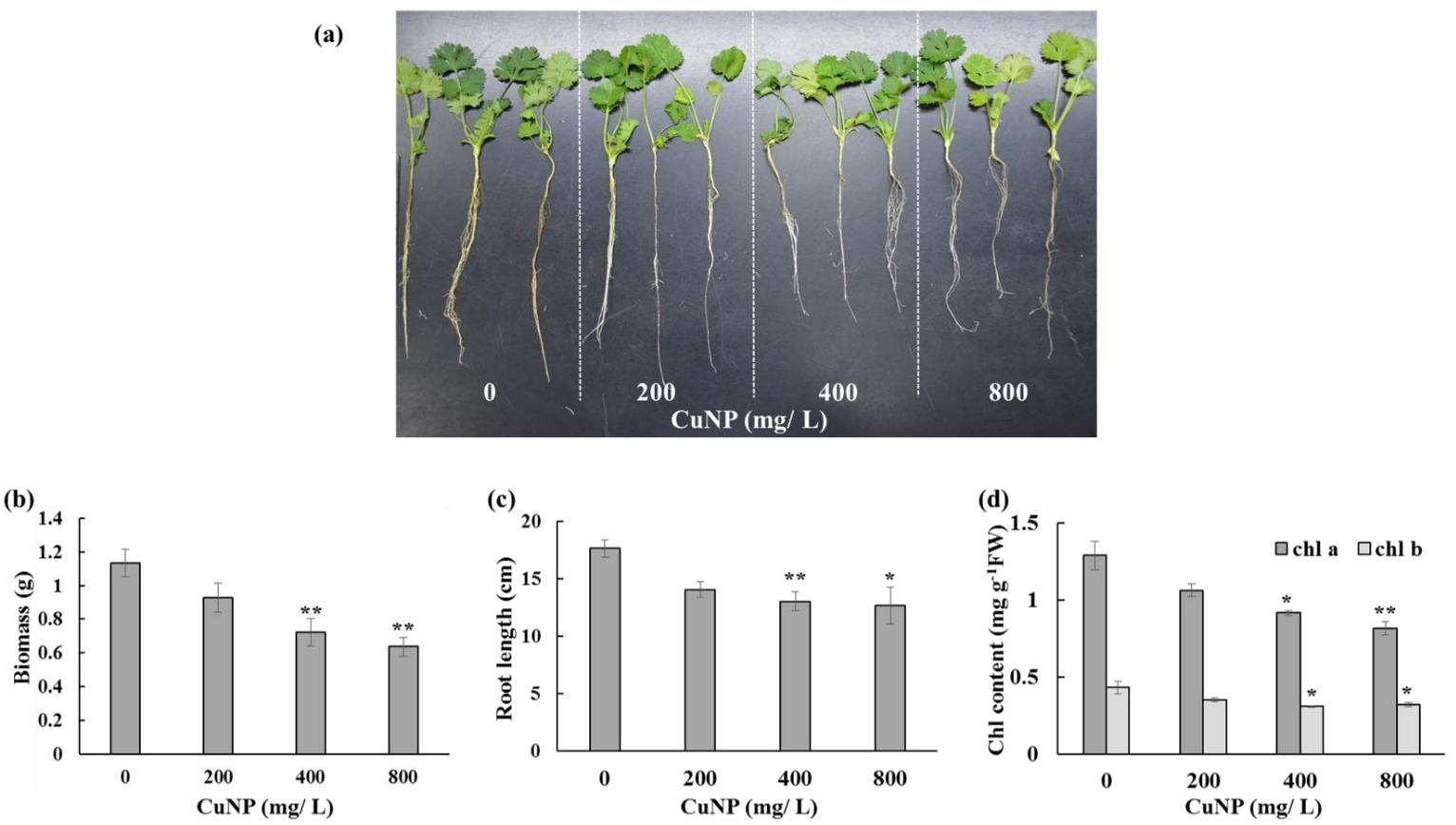

Figure 1. Phenotypic and chlorophyll analysis of C. sativum plants after 7 days of exposure to 200, 400 and $800 \mathrm{mg} / \mathrm{L}$ of CuNPs. (a) Morphology of roots and shoots of C. sativum control and treated plants. (b) Biomass of C. sativum plants. (c) Root length of $C$. sativum plants. (d) Chlorophyll a and b contents of $C$. sativum plants. The values are mean \pm se $(n=3)$. Statistically significant difference was calculated at ${ }^{*} p \leq 0.05,{ }^{* *} p \leq 0.01$.

Treated plants showed a decrease in both chlorophyll a and chlorophyll b when compared to control plants, but this response varied with the concentration of CuNP. At the lowest levels of CuNP (200 mg/L), the decrease was not significant. However, plants treated with $400 \mathrm{mg} / \mathrm{L}$ and $800 \mathrm{mg} / \mathrm{L}$ of CuNP exhibited significant decrease in both chlorophyll a and b contents (Figure 1d).

\subsection{CuNP Caused Membrane Damage on C. sativum Plants}

Root samples of the control and treated C. sativum were observed under light microscopy after Evan's blue staining. The control plants were observed to be normal under microscopy and therefore did not take the stain. In contrast, treated plants were stained according to the concentration of CuNP (Figure 2a), which demonstrated that the membrane had been damaged. Electrolyte leakage analysis showed an increase in the conductivity of the leakage solution of the $200 \mathrm{mg} / \mathrm{L}, 400 \mathrm{mg} / \mathrm{L}$ 
and $800 \mathrm{mg} / \mathrm{L}$ treated roots by 34\%, 46\% and 30\%, respectively (Figure $2 \mathrm{~b}$ ). This indicated the damage at the level of C. sativum root plasma membranes due to CuNP treatment. $800 \mathrm{mg} / \mathrm{L} \mathrm{CuNP}$ treated plants showed reduced electrolyte leakage compared to $200 \mathrm{mg} / \mathrm{L}$ and $400 \mathrm{mg} / \mathrm{L} \mathrm{CuNP}$ treated plants, possibly due to higher toxic levels of CuNP efflux from the roots.

(a)

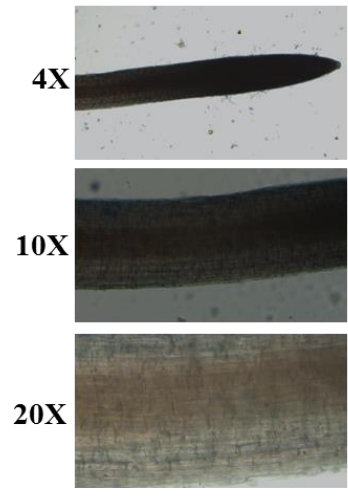

$\mathbf{0}$
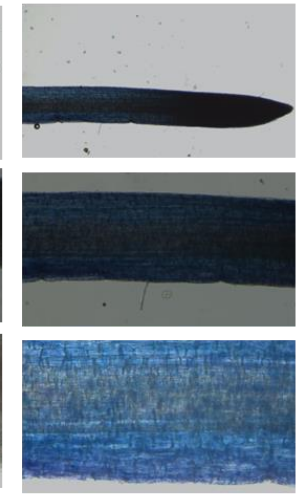

200
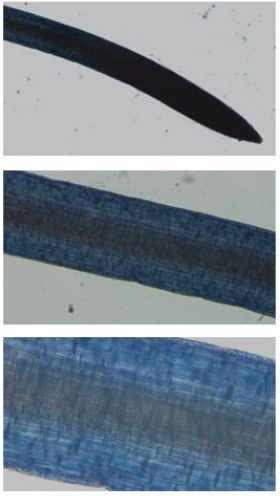

400
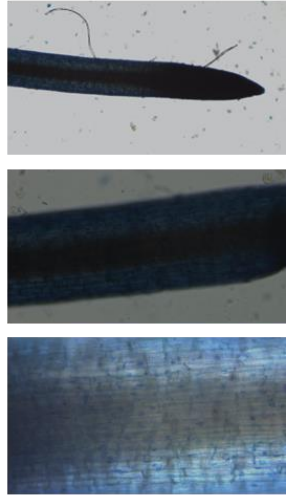

800

(b)

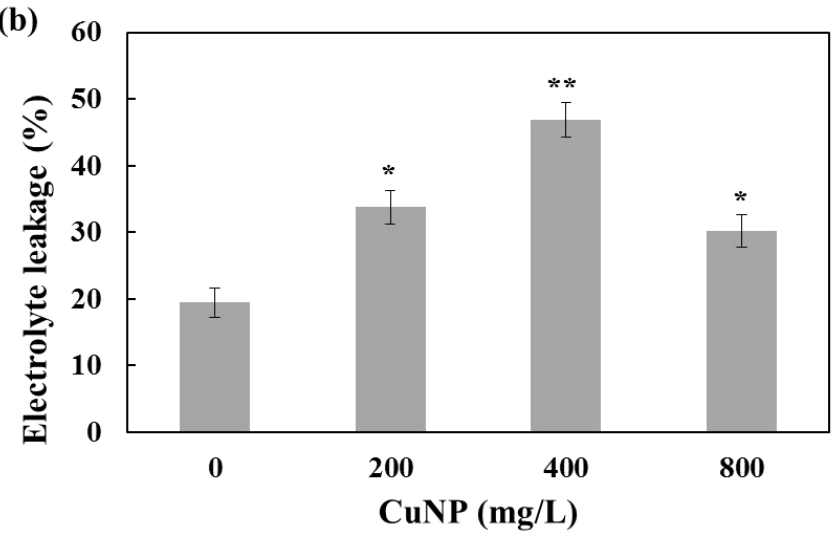

Figure 2. Evan's blue and electrolyte leakage analysis of $C$. sativum plants after 7 days of exposure to $200 \mathrm{mg} / \mathrm{L}, 400 \mathrm{mg} / \mathrm{L}$ and $800 \mathrm{mg} / \mathrm{L}$ of CuNPs. (a) plasma membrane integrity of roots monitored under $4 \times, 10 \times$ and $20 \times$ magnifications using Evan's blue staining. (b) electrolyte leakage analysis of C. sativum plants. The values are mean \pm se $(n=3)$. Statistically significant difference was calculated at ${ }^{*} p \leq 0.05,{ }^{* *} p \leq 0.01$.

\subsection{CuNP Increased Hydrogen Peroxide and Malondialdehyde Content in C. sativum Plants}

Shoots and roots were stained with $3,3^{\prime}$ - diaminobenzidine (DAB) to observe $\mathrm{H}_{2} \mathrm{O}_{2}$ production due to different concentrations of CuNP. Treated plants displayed brown spots on the leaves and brownish black roots, whereas control plants exhibited no changes in both shoots and roots (Figure $3 a, b)$. Furthermore, hydrogen peroxide $\left(\mathrm{H}_{2} \mathrm{O}_{2}\right)$ content was measured in both shoots and roots of $C$. sativum control and $\mathrm{CuNP}$ treated plants. Figure 3c,d shows that there were no significant differences in $\mathrm{H}_{2} \mathrm{O}_{2}$ levels between control and treated shoots. However, all the $\mathrm{CuNP}$ treated roots had significantly higher amounts of $\mathrm{H}_{2} \mathrm{O}_{2}$ compared to control untreated root tissues (approximately 10 to 16 -fold increase).

Regarding Malondialdehyde (MDA), in this case, CuNP treated plant shoot and root tissues had approximately 2-fold higher MDA levels in comparison to control plants (Figure 3e,f). 
(a)

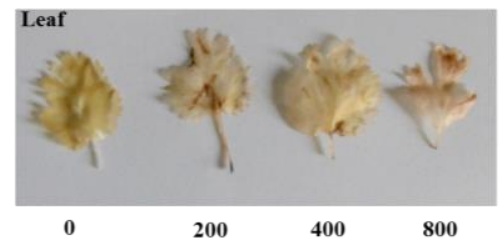

(c)

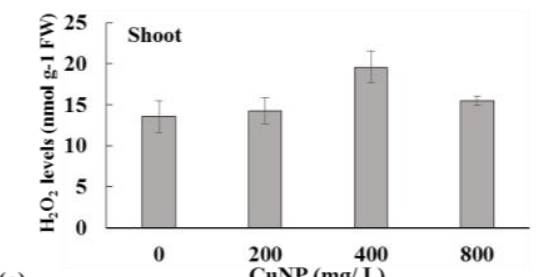

(e)

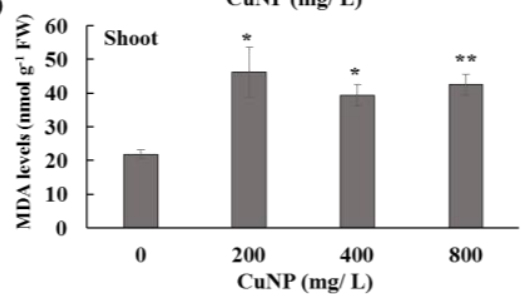

(b)

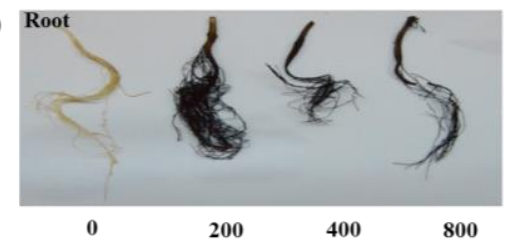

(d)

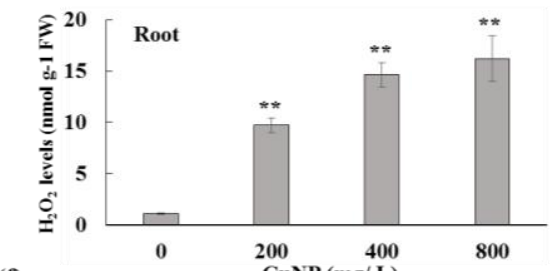

(f)

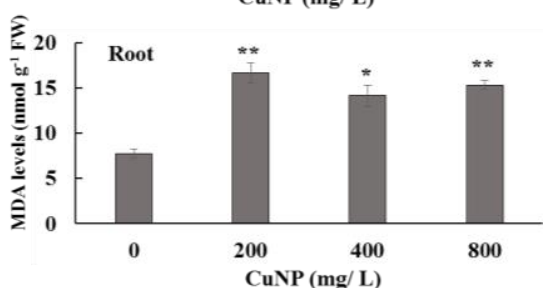

Figure 3. $\mathrm{H}_{2} \mathrm{O}_{2}$ and MDA content analysis of C. sativum plants after 7 days of exposure to 200, 400 and $800 \mathrm{mg} / \mathrm{L}$ of CuNPs. (a) DAB staining as a preliminary test for detection of $\mathrm{H}_{2} \mathrm{O}_{2}$ in shoots and (b) roots. (c) $\mathrm{H}_{2} \mathrm{O}_{2}$ levels in shoots and (d) roots. (e) MDA levels in shoots and (f) roots. The values are mean \pm se $(n=3)$. Statistically significant difference was calculated at ${ }^{*} p \leq 0.05,{ }^{* *} p \leq 0.01$.

\subsection{C. sativum Plants Accumulated more CuNP in Root Tissues}

Other than copper, elements of the Hoagland solution, such as $\mathrm{Cl}, \mathrm{Ca}, \mathrm{Si}, \mathrm{K}, \mathrm{S}$, and $\mathrm{P}$, were also detected (Figure 4). Remarkably, more copper was detected in root tissues compared to shoot tissues as demonstrated by XRF analysis (Figure 4c,d). The elemental profile of shoot and root tissues can vary in control tissues. Due to CuNP treatment, the profiles were changed in both shoot and root tissues of C. sativum plants in comparison to control plants.
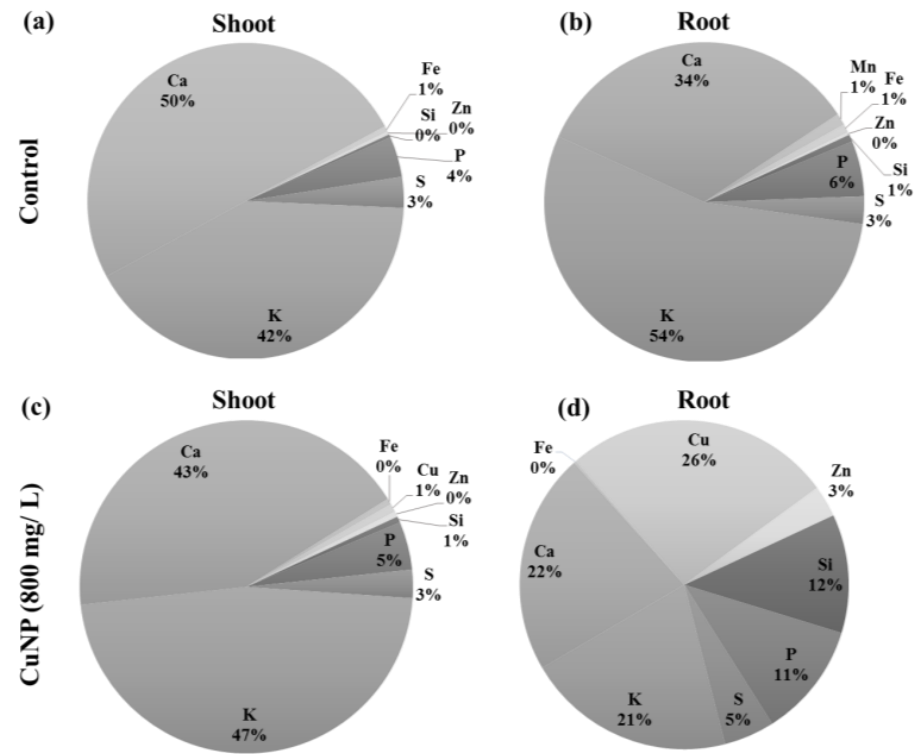

Figure 4. Elemental analysis of C. sativum plants after 7 days of exposure to $800 \mathrm{mg} / \mathrm{L}$ of CuNPs by XRF. (a) control shoot (b) control root (c) $800 \mathrm{mg} / \mathrm{L} \mathrm{CuNPs}$ treated shoot and (d) $800 \mathrm{mg} / \mathrm{L} \mathrm{CuNPs}$ treated roots. Elemental profiles were obtained from three biological replicates. 


\subsection{CuNP Induced Genotoxicity in C. satioum Plants}

Random Amplified Polymorphic DNA (RAPD) was performed to assess CuNP phytotoxicity effect at the genomic level of C. sativum (Figure 5). Extracted genomic DNA from the roots of both control and CuNP treated samples were amplified using several sets of primers (OPA-01, OPA-02, OPA-06 and OPA-07). The amplified control sample of the OPA- 01 primer showed seven bands ranging between 200 to $1200 \mathrm{bps}$. For the $200 \mathrm{mg} / \mathrm{L}, 400 \mathrm{mg} / \mathrm{L}$ and $800 \mathrm{mg} / \mathrm{L} \mathrm{CuNP}$ treatments, the amplified DNA demonstrated the same bands as the control DNA samples, except that all treatments had lost one band at 1200 bps. Control sample DNA for the OPA-02 primer amplified several bands ranging between 200 to 1200 bps. However, samples treated with 400 and $800 \mathrm{mg} / \mathrm{L} \mathrm{CuNP}$ exhibited absence of the band at 1000 bps. Control sample DNA amplified with the OPA-06 primer presented eight bands ranging between 150 bps to 1000 bps. Samples treated with $200 \mathrm{mg} / \mathrm{L}, 400 \mathrm{mg} / \mathrm{L}$ and $800 \mathrm{mg} / \mathrm{L}$ CuNP showed one missing band at 700 bps. In addition, control sample DNA amplified with the OPA-07 primer presented six bands ranging between $150 \mathrm{bps}$ to $1200 \mathrm{bps}$. Samples treated with $200 \mathrm{mg} / \mathrm{L}$ demonstrated the same pattern as controls whereas $400 \mathrm{mg} / \mathrm{L}$ and $800 \mathrm{mg} / \mathrm{L} \mathrm{CuNP}$ presented an additional band at 700 bps. Overall, the RAPD results demonstrated that CuNPs made significant changes in the genome of the C. sativum plants.

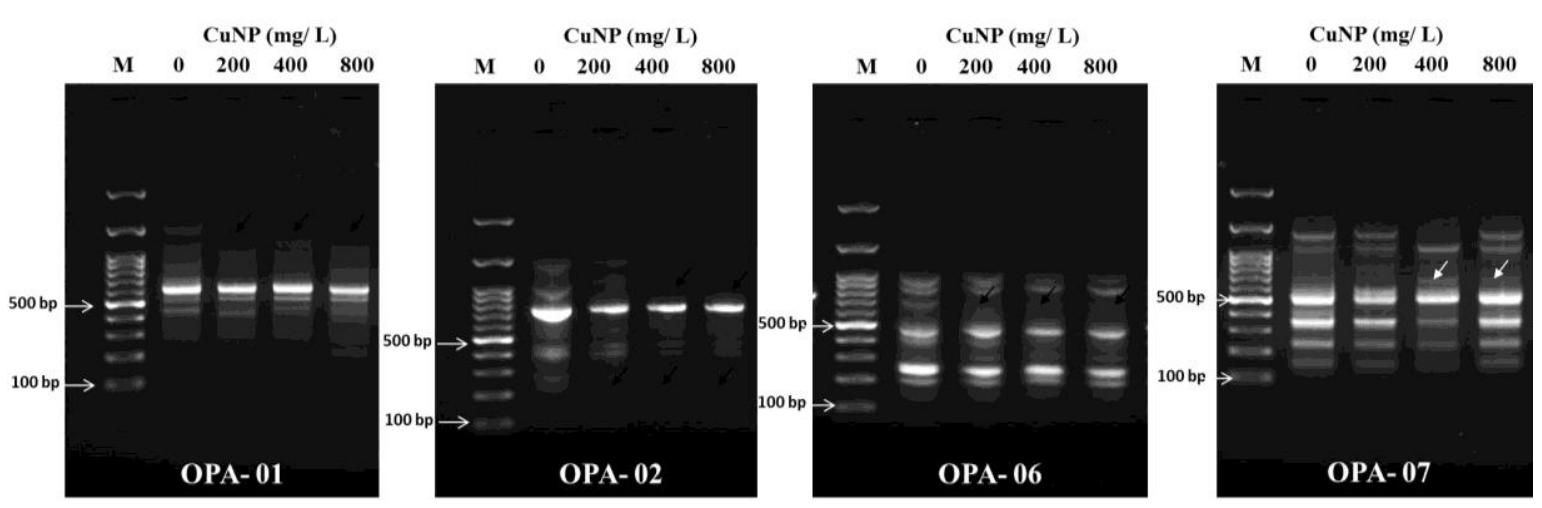

Figure 5. Random amplified polymorphic DNA (RAPD) analysis of $C$. sativum plants after seven days of exposure to $200 \mathrm{mg} / \mathrm{L}, 400 \mathrm{mg} / \mathrm{L}$ and $800 \mathrm{mg} / \mathrm{L}$ of CuNPs. All DNA of control and treated plants were amplified with OPA-1, OPA-2, OPA-6 and OPA-7. The white arrows indicate the disappearance and appearance of bands between control and treated plants.

\section{Discussion}

C. sativum grown hydroponically allows more accessibility to the plant and easier controlled manipulation of nutrients when compared to soil due to complex ion interactions [24]. Coriander plants treated with different concentrations of CuNP (200, 400 and $800 \mathrm{mg} / \mathrm{L})$ for seven days exhibited a decrease in root length when compared to non-treated plants. The root length was significantly reduced at all concentrations. In our earlier report, we studied the effect of CuNPs on cucumber (C. savius) plants in which phytotoxic effects of CuNPs were demonstrated with concentrations of $50 \mathrm{mg} / \mathrm{L}, 100 \mathrm{mg} / \mathrm{L}$ and $150 \mathrm{mg} / \mathrm{L}$ CuNPs. Interestingly, our preliminary experiments with coriander did not show any phytotoxic effects utilizing the same concentrations of CuNPs (data not shown) even though the same CuNPs were utilized in the earlier cucumber plants study. When we increased the concentration to the reported concentration here $(200 \mathrm{mg} / \mathrm{L}, 400 \mathrm{mg} / \mathrm{L}$ and $800 \mathrm{mg} / \mathrm{L})$, clear phototoxic effects were seen. These variations are clearly due to the effect of the plant species itself. Hence, coriander plants were able to tolerate CuNP levels without producing the phytotoxic effects observed in cucumber plants. Moreover, coriander's ability to tolerate and remediate toxic metals has been reported recently. Adsorption capacity and efficiency of coriander in removal of $\mathrm{Pb}^{2+}, \mathrm{Cd}^{2+}$ ions and turbidity from simulated contaminated water was reported [25]. Additionally, C. sativum 
plants showed considerable potential for phytoremediation of $\mathrm{Pb}$ and As from contaminated soil and water [26].

CuNP treated coriander showed brown color as well as weaker or no growth of lateral and hair roots in comparison to controls, possibly due to root accumulation of CuNP as indicated by XRF results. It was shown that rice treated with copper oxide nanoparticles exhibited reduced root and shoot length [27]. Similar results have also been reported for lettuce and alfalfa [28]. In addition, another study showed that zucchini root length was affected by CuNP [19]. This was similar to A. thaliana, where the plant growth and biomass was reduced when treated with different concentrations $(2 \mathrm{mg} / \mathrm{L}$, $5 \mathrm{mg} / \mathrm{L}, 10 \mathrm{mg} / \mathrm{L}, 20 \mathrm{mg} / \mathrm{L}, 50 \mathrm{mg} / \mathrm{L}$, and $100 \mathrm{mg} / \mathrm{L}$ ) of copper oxide nanoparticles [29].

The presence of high concentrations of endogenous $\mathrm{H}_{2} \mathrm{O}_{2}$ implies a very high rate of production under CuNP-induced stress. High accumulation of endogenous $\mathrm{H}_{2} \mathrm{O}_{2}$ levels was also evident in our CuNP stressed coriander leaves and roots, which implies that anti-oxidant enzymes are not sufficient to scavenge the excess $\mathrm{H}_{2} \mathrm{O}_{2}$. Similarly, this was also reported in rice and Syrian barley treated with copper oxide nanoparticle $(\mathrm{CuONP})[30,31]$. Additionally, $\mathrm{H}_{2} \mathrm{O}_{2}$ may act as a secondary messenger to trigger many physiological processes, as recorded under CuNP stress. Coriander plants showed high sensitivity towards CuNP and increased electrolyte leakage under CuNP treatments, the latter leading to alterations in the membrane permeability. Evan's blue was used as a marker to demonstrate that increases in CuNP concentration augmented cell membrane damage through enhanced accumulation of the dye, resulting in cell death. This was reported in cucumber treated with both cerium oxide $\left(\mathrm{CeO}_{2}\right)$ and lanthanum oxide $\left(\mathrm{La}_{2} \mathrm{O}_{3}\right)$ nanoparticles [32]. This was also reflected in the MDA results, since MDA formation is related to lipid peroxidation indicating highly significant membrane damage to our treated plant cells as compared to control plant cells. Similar results were shown in Syrian barley treated with CuONP, as well as lettuce plants treated with ceria nanoparticles [31,33]. Additionally, toxic effects of CuNP are probably exerted through free radical generation, which results in the enhanced production of MDA. Metals are known to inhibit the precursor of chlorophyll called protochlorophyllide by inhibiting the enzyme protochlorophyllide reductase [34]. The reduction is mainly due to the high redox potential of metals including copper [35]. Additionally, copper is one of the essential micronutrients for plants and should be tightly regulated. Either copper deficiency or excess copper leads to variation in plant growth and development by adverse physiological processes [10]. The chlorophyll contents were measured as a photosynthetic performance, which showed a significant reduction in the $400 \mathrm{mg} / \mathrm{L}$ and $800 \mathrm{mg} / \mathrm{L}$ treatments in comparison to control plants. This might be due to damage in chloroplast membranes as a result of excess lipid peroxidation under higher oxidative stress, or changes in leaf thickness and anatomy, or as a result of reduction in the availability of mineral elements leading to depletion of Iron ( $\mathrm{Fe}$ ) as a result of antagonism between $\mathrm{Cu}$ and Fe uptake. This has been already shown in Brassica juncea $\mathrm{L}$ and Arabidopsis treated with $\mathrm{Cu}$ and $\mathrm{CuNP}[21,36,37]$.

XRF microscopy was used for elemental analysis in plant tissues semi-quantitatively (mass \%). This was performed to show the elemental composition of $C$. sativum shoots and roots treated with CuNP. Micro-XRF analysis has also been used widely in earlier studies for elemental analysis, as shown when detecting $\mathrm{CeO}_{2}$ in the soybean epidermis [38]. In another report, micro-XRF was used to study how the $\mathrm{CeO}_{2}$ nanoparticles changed the allocation of calcium in kernel [39]. Moreover, it was used to map titanium oxide $\left(\mathrm{TiO}_{2}\right)$ distribution in wheat where it accumulated in root tissues and distributed through whole plant tissues [40]. Our elemental analysis of CuNP treated samples showed $26 \%$ and $1 \%$ of copper in roots and shoots, respectively, whereas it was undetectable in control untreated plants. Interestingly, a clear increase in $\mathrm{Si}(12 \%)$ was detected in CuNP treated roots compared to $1 \%$ in control untreated roots, which may be part of the plant coping mechanism against CuNP stress as reported previously [41].

RAPD technique is used to detect polymorphisms in the genome without prior knowledge of the DNA sequence [32]. RAPD was used to assess the genotoxicity of $\mathrm{TiO}_{2}$ in Cucurbita pepo which demonstrated DNA changes in treated versus control conditions [42]. Moreover, it has been used to 
assess the genotoxicity of cerium oxide $(\mathrm{CeO} 2)$ and titanium Oxide $\left(\mathrm{TiO}_{2}\right)$ in Hordeum vulgare $\mathrm{L}$ [43]. Furthermore, the genotoxic effect of zinc oxide $(\mathrm{ZnO})$ and copper oxide nanoparticle (CuO NP) has been shown in buckwheat (Fagopyrum esculentum) as assessed by RAPD [44]. $\mathrm{ZnO}$ and $\mathrm{CeO}_{2}$ also showed genotoxic effects in soybean plants demonstrating different DNA patterns when compared to controls [45]. Additionally, genotoxicity was demonstrated via RAPD in cucumber plants treated with CuNP [22]. In our investigation, four standard primers (OPA1, OPA4, OPA6 and OPA7) were utilized. The genomic changes were demonstrated on agarose gels as different bands that disappeared or appeared when comparing control and treated plant DNA. Appearance of new patterns may be explained by changes in the genomic DNA template stability due to mutations, large deletions or homologous recombination. Additionally, it can also indicate a change in priming sites leading to new annealing events [44]. In observing the appearance and disappearance of bands, more of the latter phenomenon was detected in our study when comparing control and treated plants. As increases in oxidative stress can lead to DNA damage, the higher presence of ROS in treated samples may cause modifications in the observed RAPD pattern [43].

In general, CuNP induced alteration of physiological, biochemical and molecular activities in C. sativum plants. Uptake and accumulation of CuNP caused oxidative stress that limited successful plant growth and development, which was more observable in roots than shoots due to direct contact between the membrane root and CuNPs. Additionally, CuNP induced lipid peroxidation led to membrane damage as observed by enhanced MDA concentrations.

\section{Materials and Methods}

\subsection{Plant Materials and Nanoparticle Treatment}

Coriander seeds used in this study were bought from a local market. CuNPs were purchased from Hengqiu Graphene Technology (Suzhou) Co., Ltd., Shanghai, China with a purity of $99.9 \%$ and an average particle size of $20 \mathrm{~nm}$. These CuNP were characterized in our earlier study [22]. Coriander seeds (Coriandrum sativum) were sterilized using 10\% bleach solutions for $5 \mathrm{~min}$ and then washed with distilled water three times. Fitted size filter papers were inserted at the bottom of sterilized petri dishes and the sterilized seeds were dispersed along $10 \mathrm{~mL}$ of distilled water for 10 days. Seedlings were then transferred into hydroponic media containing 20\% Hoagland's No.2 basal salt mixture (Sigma-Alrich, H2395) and allowed to acclimatize for another 2 weeks in a growth chamber maintained at temperatures of $21^{\circ} \mathrm{C} / 18^{\circ} \mathrm{C}$ for $20 \mathrm{~h}$ light/4h dark cycles, respectively. Control samples were grown in $20 \%$ Hoagland's solution whereas treated samples were grown in various concentrations of CuNP (200, 400 and $800 \mathrm{mg} / \mathrm{L}$ ) and prepared in 20\% Hoagland's No. 2 basal salt mixture by 30 min sonication for uniform CuNP dispersal. These solutions were then used to treat the plants for 7 days. Experiments were conducted using three replicates of 15 plants each. We developed a hydroponic system that contained 3 replicas.

\subsection{Measurement of Biomass, Root Length, and Chlorophyll Contents}

After 7 days of CuNP treatment, plant roots were washed carefully with distilled water and blotted in tissue paper. Plant fresh weight and root length were measured for the control and treated groups. For chlorophyll a and b analysis, $100 \mathrm{mg}$ of leaf tissues were ground using ice cold mortars and pestles, incubated with $5 \mathrm{~mL}$ of $80 \%$ acetone for $15 \mathrm{~min}$ at room temperature in the dark. Samples were then dissolved in 1:1 ratio with $80 \%$ acetone and absorbance was measured by spectrophotometer (Jenway 3600, Keison products, Chelmsford, UK) at $663 \mathrm{~nm}$ and $645 \mathrm{~nm}$ for chlorophyll a and b respectively [46].

\subsection{Root Membrane Integrity}

$100 \mathrm{mg}$ of plant root was excised and added to $10 \mathrm{~mL}$ of deionized water in test tubes. The electrical conductivity was measured by an electrical conductivity meter (EC meter) after $48 \mathrm{~h}$ of 
incubation in deionized water $\left(C_{n}\right)$, and after boiling and allowing them to cool down $\left(C_{f}\right)$. Electrolyte leakage was calculated using the following formula; $E_{T} \%=\left(C_{n} / C_{f}\right) \times 100$ [47]. Experiments were conducted with three replicates, with each replica comprising a total of 15 plant roots. Plant root cell death was evaluated following treatment with CuNP by performing Evan's blue staining [48]. The control and treated plant roots were stained with $0.25 \% v / v$ of Evan's Blue in $0.1 \mathrm{M}$ calcium chloride $\left(\mathrm{CaCl}_{2}\right)$ solution for $15 \mathrm{~min}$. Subsequently, roots were washed well in distilled water to remove the excess unbound dye. Root tips were analyzed under bright field microscope (Optika B-1000 BF, Ponteranica, Italy) under different magnifications.

\subsection{Lipid per Oxidation and $\mathrm{H} 2 \mathrm{O} 2$ Determination}

Concentration of malondialdehyde (MDA) was measured for lipid peroxidation determination according to Zhou and Leul [49]. $0.1 \mathrm{~g}$ of roots and shoots were mixed with $0.1 \%(v / w)$ Trichloroacetic acid (TCA). The tubes were centrifuged at $12,000 \mathrm{~g}$ for $15 \mathrm{~min}$ at $4{ }^{\circ} \mathrm{C} .800 \mu \mathrm{L}$ of the supernatant were mixed with $2 \mathrm{~mL}$ of $0.5 \%$ 2-Thiobarbituric acid (TBA) diluted in $20 \%$ TCA. This mixture was incubated in a water bath maintained at $80^{\circ} \mathrm{C}$ for $1 \mathrm{~h}$ and allowed to cool down. Tubes were centrifuged for $5 \mathrm{~min}$ at $12,000 \mathrm{~g}$ and $4{ }^{\circ} \mathrm{C}$. Optical density was measured by spectrophotometer (Jenway 3600, Keison products, Chelmsford, UK) at $532 \mathrm{~nm}$ and $600 \mathrm{~nm}$. The concentration of MDA was calculated by using an extinction coefficient of $155 \mathrm{mM}^{-1} \mathrm{~cm}^{-1}$.

$\mathrm{H}_{2} \mathrm{O}_{2}$ contents were measured as described previously [50]. $100 \mathrm{mg}$ of frozen shoots and roots were homogenized with $2 \mathrm{~mL}$ of $0.1 \%$ TCA solution and then centrifuged at $12,000 \mathrm{~g}$ for $15 \mathrm{~min}$ at $4{ }^{\circ} \mathrm{C}$. The clear supernatant $(0.5 \mathrm{~mL})$ was mixed with $0.5 \mathrm{~mL}$ of $10 \mathrm{mM}$ potassium phosphate buffer ( $\mathrm{pH} 7$ ) and $1 \mathrm{~mL}$ of $1 \mathrm{M}$ potassium iodide and optical density were measured by spectrophotometer (Jenway 3600, Keison products, $\mathrm{UK}$ ) at $390 \mathrm{~nm}$. The $\mathrm{H}_{2} \mathrm{O}_{2}$ content was determined using an extinction coefficient of $0.28 \mu \mathrm{m} \mathrm{cm}^{-1}$ and expressed as $\mu \mathrm{mol} \cdot \mathrm{g}^{-1} \mathrm{FW} . \mathrm{H}_{2} \mathrm{O}_{2}$ accumulation was detected using a $3^{\prime}, 3^{\prime}$-diaminobenzidine (DAB) assay [51]. The control and treated plant leaf and roots were stained with $1 \mathrm{mg} \cdot \mathrm{mL}^{-1} \mathrm{DAB}$ solution and incubated in a shaker for $4 \mathrm{~h}$ by covering it with foil. The tissues were washed with ethanol, acetic acid and glycerol (3:1:1) and incubated in a $90^{\circ} \mathrm{C}$ water bath to bleach the chlorophyll content. Subsequently, the leaf and roots were photographed with a white background.

\subsection{X-ray Fluorescence (XRF) Analysis of CuNP in Plant Tissues}

Dry samples were prepared by drying the roots and shoots in an oven $\left(65^{\circ} \mathrm{C}\right)$. Using Horiba's XGT 7200, X-ray Analytical Microscope (XAM), elemental composition of the control and CuNP treated plant samples were measured semi-quantitatively as described previously [22]. This microscope facilitates collecting spectra either from a specific spot or particular area in our samples. Oven dried control and CuNP treated plant samples were used for measuring elemental composition using XAM.

\subsection{DNA Extraction and RAPD Analysis}

DNA was extracted from root samples stored at $-80^{\circ} \mathrm{C}$ using a Norgen Biotek DNA extraction kit for plant/fungi according to manufacturer instructions. DNA samples were quantified using nanodrop 2000 (Thermo Fischer Scientific, Waltham, MA, USA). A similar concentration of DNA was used with Norgen Biotek Corp master mix using the RAPD primers OPA-1 (CAGGCCCTTC), OPA-2 (TGCCGAGCTG), OPA-6 (GGTCCCTGAC), and OPA-7 (GAAACGGGTG). The RAPD PCR program was set to initial denaturation at $95^{\circ} \mathrm{C}$ for $3 \mathrm{~min}$, followed by a 35-cycle annealing step set at $48^{\circ} \mathrm{C}$ for $1 \mathrm{~min}$, extension of products at $72{ }^{\circ} \mathrm{C}$ for $2 \mathrm{~min}$ and the final extension set at $72{ }^{\circ} \mathrm{C}$ for $7 \mathrm{~min}$ using the Techne PCR machine (TC-5000) (GMI Inc., Ramsey, MN, USA). PCR amplified samples were run on $2 \%$ agarose gel electrophoresis along with molecular marker (1 kb promega molecular weight marker) and photographed using the Biorad gel doc system. 


\section{Conclusions}

In conclusion, to our knowledge, this is the first report focused on evaluating the phytotoxic effect of CuNP in C. sativum. XRF analysis demonstrated that CuNP $(20 \mathrm{~nm})$ had a toxic effect on C. sativum root length and biomass where both decreased significantly in accordance with increasing CuNP concentration, along with a significant decrease in total chlorophyll content. Moreover, damage in the membranes of treated samples was demonstrated by an increase in electrolyte leakage as observed by Evan's blue studies. In addition, an increase in endogenous $\mathrm{H}_{2} \mathrm{O}_{2}$ and MDA formation was observed in C. Sativum plants treated with CuNP.

Furthermore, from the molecular perspective, DNA damage was assessed by utilizing the RAPD technique which showed different patterns of bands between control and treated plants. Further studies are needed to better understand the molecular mechanisms underlying CuNP transport and accumulation in important leafy herbal plants such as C. sativum.

Author Contributions: Conceptualization, K.A.M.; formal analysis, A.O.A., K.R., K.A.M.; investigation, A.O.A., K.A.M.; resources, K.A.M.; data curation A.O.A., K.R., K.A.M.; writing-original draft preparation, A.O.A.; writing-review and editing, K.A.M., K.R.; supervision, K.A.M.; project administration, K.A.M.

Funding: This research was financially supported by the Office of VC for Research and Graduate Studies at the University of Sharjah.

Acknowledgments: We would like to thank Hussain Alawadhi, Attiat Elnaggar, and Mohamed Shameer for their assistance.

Conflicts of Interest: The authors declare no conflict of interest.

\section{References}

1. Khot, L.R.; Sankaran, S.; Maja, J.M.; Ehsani, R.; Schuster, E.W. Applications of nanomaterials in agricultural production and crop protection: A review. Crop Prot. 2012, 35, 64-70. [CrossRef]

2. Guo, H.; Barnard, A.S. Naturally occurring iron oxide nanoparticles: Morphology, surface chemistry and environmental stability. J. Mater. Chem. A 2013, 1, 27-42. [CrossRef]

3. Kumar, P.; Kumar, A.; Lead, J.R. Nanoparticles in the Indian Environment: Known, Unknowns and Awareness. Environ. Sci. Technol. 2012, 46, 7071-7072. [CrossRef] [PubMed]

4. Bhatt, I.; Tripathi, B.N. Interaction of engineered nanoparticles with various components of the environment and possible strategies for their risk assessment. Chemosphere 2011, 82, 308-317. [CrossRef]

5. Fabrega, J.; Luoma, S.N.; Tyler, C.R.; Galloway, T.S.; Lead, J.R. Silver nanoparticles: Behaviour and effects in the aquatic environment. Environ. Int. 2011, 37, 517-531. [CrossRef]

6. Bystrzejewska-Piotrowska, G.; Golimowski, J.; Urban, P.L. Nanoparticles: Their potential toxicity, waste and environmental management. Waste Manag. 2009, 29, 2587-2595. [CrossRef] [PubMed]

7. Athanassiou, E.K.; Grass, R.N.; Stark, W.J. Large-scale production of carbon-coated copper nanoparticles for sensor applications. Nanotechnology 2006, 17, 1668. [CrossRef]

8. Lee, Y.; Choi, J.R.; Lee, K.J.; Stott, N.E.; Kim, D. Large-scale synthesis of copper nanoparticles by chemically controlled reduction for applications of inkjet-printed electronics. Nanotechnology 2008, 19, 415604. [CrossRef]

9. Oberdürster, G. Toxicology of ultrafine particles: In vivo studies. Philos. Trans. R. Soc. Lond. Ser. A 2000, 358, 2719. [CrossRef]

10. Yruela, I. Copper in plants. Braz. J. Plant Physiol. 2005, 17, 145-156. [CrossRef]

11. Sommer, A.L. Copper as an essential for plant growth. Plant Physiol. 1931, 6, 339. [CrossRef] [PubMed]

12. Nagajyoti, P.C.; Lee, K.D.; Sreekanth, T.V.M. Heavy metals, occurrence and toxicity for plants: A review. Environ. Chem. Lett. 2010, 8, 199-216. [CrossRef]

13. Tripathi, D.K.; Singh, S.; Singh, S.; Pandey, R.; Singh, V.P.; Sharma, N.C.; Prasad, S.M.; Dubey, N.K.; Chauhan, D.K. An overview on manufactured nanoparticles in plants: Uptake, translocation, accumulation and phytotoxicity. Plant Physiol. Biochem. 2017, 110, 2-12. [CrossRef] [PubMed]

14. Faisal, M.; Saquib, Q.; Alatar, A.A.; Al-Khedhairy, A.A. Phytotoxicity of Nanoparticles; Springer: Berlin, Germany, 2018. 
15. Ravishankar Rai, V.; Jamuna Bai, A. Nanoparticles and Their Potential Application as Antimicrobials; Méndez-Vilas, A., Ed.; Formatex: Mysore, India, 2011.

16. Palza, H. Antimicrobial Polymers with Metal Nanoparticles. Int. J. Mol. Sci. 2015, 16, 2099-2116. [CrossRef] [PubMed]

17. Kiaune, L.; Singhasemanon, N. Pesticidal copper (I) oxide: Environmental fate and aquatic toxicity. Rev. Environ. Contam. Toxicol. 2011, 213, 1-26. [CrossRef] [PubMed]

18. Ponmurugan, P.; Manjukarunambika, K.; Elango, V.; Gnanamangai, B.M. Antifungal activity of biosynthesised copper nanoparticles evaluated against red root-rot disease in tea plants. J. Exp. Nanosci. 2016, 11, 1019-1031. [CrossRef]

19. Stampoulis, D.; Sinha, S.K.; White, J.C. Assay-Dependent Phytotoxicity of Nanoparticles to Plants. Environ. Sci. Technol. 2009, 43, 9473-9479. [CrossRef]

20. Shi, J.; Peng, C.; Yang, Y.; Yang, J.; Zhang, H.; Yuan, X.; Chen, Y.; Hu, T. Phytotoxicity and accumulation of copper oxide nanoparticles to the Cu-tolerant plant Elsholtzia splendens. Nanotoxicology 2014, 8, 179-188. [CrossRef]

21. Nair, P.M.G.; Chung, I.M. Study on the correlation between copper oxide nanoparticles induced growth suppression and enhanced lignification in Indian mustard (Brassica juncea L.). Ecotoxicol. Environ. Saf. 2015, 113, 302-313. [CrossRef]

22. Mosa, K.A.; El-Naggar, M.; Ramamoorthy, K.; Alawadhi, H.; Elnaggar, A.; Wartanian, S.; Ibrahim, E.; Hani, H. Copper Nanoparticles Induced Genotoxicity, Oxidative Stress, and Changes in Superoxide Dismutase (SOD) Gene Expression in Cucumber (Cucumis sativus) Plants. Front. Plant Sci. 2018, 9, 872. [CrossRef]

23. Atha, D.H.; Wang, H.; Petersen, E.J.; Cleveland, D.; Holbrook, R.D.; Jaruga, P.; Dizdaroglu, M.; Xing, B.; Nelson, B.C. Copper Oxide Nanoparticle Mediated DNA Damage in Terrestrial Plant Models. Environ. Sci. Technol. 2012, 46, 1819-1827. [CrossRef] [PubMed]

24. Conn, S.J.; Hocking, B.; Dayod, M.; Xu, B.; Athman, A.; Henderson, S.; Aukett, L.; Conn, V.; Shearer, M.K.; Fuentes, S.; et al. Protocol: Optimising hydroponic growth systems for nutritional and physiological analysis of Arabidopsis thaliana and other plants. Plant Methods 2013, 9, 4. [CrossRef] [PubMed]

25. Kivuti, N.M. Using Cilantro Leaves and Stems to Remove Lead, Cadmium and Turbidity from Contaminated Water; Kenyatta University: Kenya, Nairobi, 2017.

26. Gaur, N.; Kukreja, A.; Yadav, M.; Tiwari, A. Assessment of phytoremediation ability of Coriander sativum for soil and water co-contaminated with lead and arsenic: A small-scale study. 3 Biotech 2017, 7, 196. [CrossRef] [PubMed]

27. Da Costa, M.V.J.; Sharma, P.K. Effect of copper oxide nanoparticles on growth, morphology, photosynthesis, and antioxidant response in Oryza sativa. Photosynthetica 2016, 54, 110-119. [CrossRef]

28. Hong, J.; Rico, C.M.; Zhao, L.; Adeleye, A.S.; Keller, A.A.; Peralta-Videa, J.R.; Gardea-Torresdey, J.L. Toxic effects of copper-based nanoparticles or compounds to lettuce (Lactuca sativa) and alfalfa (Medicago sativa). Environ. Sci. Process. Impacts 2015, 17, 177-185. [CrossRef] [PubMed]

29. Nair, P.M.G.; Chung, I.M. Impact of copper oxide nanoparticles exposure on Arabidopsis thaliana growth, root system development, root lignificaion, and molecular level changes. Environ. Sci. Pollut. Res. 2014, 21, 12709-12722. [CrossRef] [PubMed]

30. Shaw, A.K.; Hossain, Z. Impact of nano-CuO stress on rice (Oryza sativa L.) seedlings. Chemosphere 2013, 93, 906-915. [CrossRef]

31. Shaw, A.K.; Ghosh, S.; Kalaji, H.M.; Bosa, K.; Brestic, M.; Zivcak, M.; Hossain, Z. Nano-CuO stress induced modulation of antioxidative defense and photosynthetic performance of Syrian barley (Hordeum vulgare L.). Environ. Exp. Bot. 2014, 102, 37-47. [CrossRef]

32. Dingle, T.C.; MacCannell, D.R. Chapter 9-Molecular Strain Typing and Characterisation of Toxigenic Clostridium difficile. In Methods in Microbiology; Sails, A., Tang, Y.-W., Eds.; Academic Press: Cambridge, MA, USA, 2015; Volume 42, pp. 329-357.

33. Gui, X.; Zhang, Z.; Liu, S.; Ma, Y.; Zhang, P.; He, X.; Li, Y.; Zhang, J.; Li, H.; Rui, Y.; et al. Fate and Phytotoxicity of $\mathrm{CeO}_{2}$ Nanoparticles on Lettuce Cultured in the Potting Soil Environment. PLoS ONE 2015, 10, e0134261. [CrossRef]

34. De Filippis, L.F.; Ziegler, H. Effect of Sublethal Concentrations of Zinc, Cadmium and Mercury on the Photosynthetic Carbon Reduction Cycle of Euglena. J. Plant Physiol. 1993, 142, 167-172. [CrossRef] 
35. Chandra, R.; Kang, H. Mixed heavy metal stress on photosynthesis, transpiration rate, and chlorophyll content in poplar hybrids. For. Sci. Technol. 2016, 12, 55-61. [CrossRef]

36. Lequeux, H.; Hermans, C.; Lutts, S.; Verbruggen, N. Response to copper excess in Arabidopsis thaliana: Impact on the root system architecture, hormone distribution, lignin accumulation and mineral profile. Plant Physiol. Biochem. 2010, 48, 673-682. [CrossRef] [PubMed]

37. Feigl, G.; Kumar, D.; Lehotai, N.; Tugyi, N.; Molnar, A.; Ordog, A.; Szepesi, A.; Gemes, K.; Laskay, G.; Erdei, L.; et al. Physiological and morphological responses of the root system of Indian mustard (Brassica juncea $\mathrm{L}$. Czern.) and rapeseed (Brassica napus L.) to copper stress. Ecotoxicol. Environ. Saf. 2013, 94, 179-189. [CrossRef]

38. Hernandez-Viezcas, J.A.; Castillo-Michel, H.; Andrews, J.C.; Cotte, M.; Rico, C.; Peralta-Videa, J.R.; Ge, Y.; Priester, J.H.; Holden, P.A.; Gardea-Torresdey, J.L. In Situ Synchrotron X-ray Fluorescence Mapping and Speciation of $\mathrm{CeO}_{2}$ and $\mathrm{ZnO}$ Nanoparticles in Soil Cultivated Soybean (Glycine max). ACS Nano 2013, 7, 1415-1423. [CrossRef] [PubMed]

39. Zhao, L.; Sun, Y.; Hernandez-Viezcas, J.A.; Hong, J.; Majumdar, S.; Niu, G.; Duarte-Gardea, M.; Peralta-Videa, J.R.; Gardea-Torresdey, J.L. Monitoring the environmental effects of $\mathrm{CeO}_{2}$ and $\mathrm{ZnO}$ nanoparticles through the life cycle of corn (Zea mays) plants and in situ mu-XRF mapping of nutrients in kernels. Environ. Sci. Technol. 2015, 49, 2921-2928. [CrossRef]

40. Larue, C.; Laurette, J.; Herlin-Boime, N.; Khodja, H.; Fayard, B.; Flank, A.-M.; Brisset, F.; Carriere, M. Accumulation, translocation and impact of $\mathrm{TiO}_{2}$ nanoparticles in wheat (Triticum aestivum spp.): Influence of diameter and crystal phase. Sci. Total Environ. 2012, 431, 197-208. [CrossRef] [PubMed]

41. Li, J.; Leisner, S.M.; Frantz, J. Alleviation of copper toxicity in Arabidopsis thaliana by silicon addition to hydroponic solutions. J. Am. Soc. Hort. Sci. 2008, 133, 670-677.

42. Moreno-Olivas, F.; Gant, V.U.; Johnson, K.L.; Peralta-Videa, J.R.; Gardea-Torresdey, J.L. Random amplified polymorphic DNA reveals that $\mathrm{TiO}_{2}$ nanoparticles are genotoxic to Cucurbita pepo. J. Zhejiang Univ. Sci. A 2014, 15, 618-623. [CrossRef]

43. Mattiello, A.; Filippi, A.; Pošćić, F.; Musetti, R.; Salvatici, M.C.; Giordano, C.; Vischi, M.; Bertolini, A.; Marchiol, L. Evidence of Phytotoxicity and Genotoxicity in Hordeum vulgare L. Exposed to $\mathrm{CeO}_{2}$ and $\mathrm{TiO}_{2}$ Nanoparticles. Front. Plant Sci. 2015, 6. [CrossRef]

44. Lee, S.; Chung, H.; Kim, S.; Lee, I. The Genotoxic Effect of ZnO and CuO Nanoparticles on Early Growth of Buckwheat, Fagopyrum Esculentum. Water Air Soil Pollut. 2013, 224, 1668. [CrossRef]

45. López-Moreno, M.L.; de la Rosa, G.; Hernández-Viezcas, J.Á.; Castillo-Michel, H.; Botez, C.E.; Peralta-Videa, J.R.; Gardea-Torresdey, J.L. Evidence of the Differential Biotransformation and Genotoxicity of $\mathrm{ZnO}$ and $\mathrm{CeO}_{2}$ Nanoparticles on Soybean (Glycine max) Plants. Environ. Sci. Technol. 2010, 44, 7315-7320. [CrossRef] [PubMed]

46. Lichtenthaler, H.K.; Wellburn, A.R. Determinations of total carotenoids and chlorophylls a and b of leaf extracts in different solvents. Biochem. Soc. Trans. 1983, 11, 591. [CrossRef]

47. Liu, X.; Huang, B. Cytokinin Effects on Creeping Bentgrass Response to Heat Stress. Crop Sci. 2002, 42, 466-472. [CrossRef]

48. Zanardo, D.I.L.; Lima, R.B.; Ferrarese, M.d.L.L.; Bubna, G.A.; Ferrarese-Filho, O. Soybean root growth inhibition and lignification induced by p-coumaric acid. Environ. Exp. Bot. 2009, 66, 25-30. [CrossRef]

49. Zhou, W.; Leul, M. Uniconazole-induced alleviation of freezing injury in relation to changes in hormonal balance, enzyme activities and lipid peroxidation in winter rape. Plant Growth Regul. 1998, 26, 41-47. [CrossRef]

50. Velikova, V.; Yordanov, I.; Edreva, A. Oxidative stress and some antioxidant systems in acid rain-treated bean plants: Protective role of exogenous polyamines. Plant Sci. 2000, 151, 59-66. [CrossRef]

51. Thordal-Christensen, H.; Zhang, Z.; Wei, Y.; Collinge, D.B. Subcellular localization of $\mathrm{H}_{2} \mathrm{O}_{2}$ in plants. $\mathrm{H}_{2} \mathrm{O}_{2}$ accumulation in papillae and hypersensitive response during the barley-Powdery mildew interaction. Plant J. 2002, 11, 1187-1194. [CrossRef]

(c) 2019 by the authors. Licensee MDPI, Basel, Switzerland. This article is an open access article distributed under the terms and conditions of the Creative Commons Attribution (CC BY) license (http:/ / creativecommons.org/licenses/by/4.0/). 